\title{
Rola Funduszu Aktywizacji Zawodowej Skazanych w społecznej readaptacji osób odbywających karę pozbawienia wolności
}

The role of the Fund for the Occupational Activation of Convicts in social rehabilitation of persons undergoing the penalty of deprivation of liberty

Роль Фонда поддержания профессиональной деятельности заключенных в социальной реадаптации лиц, отбывающих наказание в виде лишения свободы

\author{
AGNIESZKA LEWICKA-ZELENT \\ Dr. hab., prof. Uniwersytetu Marii Curie-Skłodowskiej w Lublinie \\ e-mail: agnieszka.lewicka@poczta.umcs.lublin.pl, https://orcid.org/0000-0002-6967-8966 \\ SŁAWOMIR STASIOROWSKI \\ Dr, Chrześcijańska Akademia Teologiczna w Warszawie \\ e-mail: slawomir.stasiorowski@gmail.com, https://orcid.org/ 0000-0002-5451-6171
}

\begin{abstract}
Streszczenie: Zagadnienia prezentowane przez autorów w niniejszym artykule skupiają się na ukazaniu istoty funkcjonowania Funduszu Aktywizacji Zawodowej Skazanych oraz Rozwoju Przywięziennych Zakładów Pracy, który odgrywa kluczowe znaczenie dla działań wspierających społeczną readaptację skazanych prowadzonych przez Służbę Więzienną. Szczegółowo omówiono zasady jego funkcjonowania w świetle długoterminowych trendów zatrudnienia osób odbywających karę pozbawienia wolności w Polsce, prezentując je w sposób graficzny na schemacie. Autorzy zwrócili uwagę na uniwersalne znaczenie pracy w resocjalizacji oraz w życiu każdego człowieka, szczególnie pozostającego w sytuacji uwięzienia, jako jednego z zasadniczych elementów jego prawa do godności.
\end{abstract}

Słowa kluczowe: społeczna readaptacja, praca więźniów, Służba Więzienna, Fundusz Aktywizacji Zawodowej Skazanych

Summary: The issues presented by the authors in this article focus on conveying the essence of the functioning of the Fund for the Occupational Activation of Prisoners and the Development of Prison Work Establishments, which is of major importance for the activities supporting the social rehabilitation of convicts, as conducted by the Prison Service. There is a detailed discussion of the principles of its functioning in the light of the long-term trends of the employment of the persons deprived of liberty in Poland, along with it being depicted on a chart. The authors draw attention to a universal significance of work in the rehabilitation and life of every human being, in particular ones being incarcerated, as one of the fundamental components of their right to dignity.

Key words: social rehabilitation, prisoners' work, Prison Service, Fund for Occupational Activation of Convicts

Резюме: Вопросы, представленные авторами в данной статье, направлены на то, чтобы показать суть функционирования Фонда профессиональной активации заключенных и развития пенитенциарной службы занятости, который играет ключевую роль в деятельности по социальной реадаптации заключенных, осуществляемой Тюремной службой. Принципы его функционирования были подробно рассмотрены в свете долгосрочных тенденций в сфере занятости лиц, отбывающих наказание в Польше, с представлением их в графическом виде на диаграмме. Авторы обратили внимание на универсальное значение труда в ресоциализации и в жизни каждого человека, особенно тех, кто находится в заключении, как одного из существенных элементов их права на достоинство.

Ключевые слова: социальная реадаптация, труд заключенных, Тюремная служба, Фонд поддержания профессиональной деятельности заключенных 


\section{Wstęp}

Praca jest jednym $z$ determinantów określających sens istnienia człowieka. Jan Paweł II uważał, że

Z pracy swojej ma człowiek pożywać chleb codzienny i poprzez pracę ma się przyczyniać do ciągłego rozwoju nauki i techniki, a zwłaszcza do nieustannego podnoszenia poziomu kulturalnego i moralnego społeczeństwa, w którym żyje jako członek braterskiej wspólnoty; praca zaś oznacza każdą działalność, jaką człowiek spełnia, bez względu na jej charakter i okoliczności, to znaczy każdą działalność człowieka, którą za pracę uznać można i uznać należy pośród całego bogactwa czynności, do jakich jest zdolny i dysponowany poprzez samą swoją naturę, poprzez samo człowieczeństwo. Stworzony bowiem na obraz i podobieństwo Boga Samego wśród widzialnego wszechświata, ustanowiony, aby ziemię czynić sobie poddaną, jest człowiek przez to samo od początku powołany do pracy. Praca wyróżnia go wśród reszty stworzeń, których działalności związanej z utrzymaniem życia nie można nazywać pracą - tylko człowiek jest do niej zdolny i tylko człowiek ją wykonuje, wypełniając równocześnie pracą swoje bytowanie na ziemi. Tak więc praca nosi na sobie szczególne znamię człowieka i człowieczeństwa, znamię osoby działającej we wspólnocie osób - a znamię to stanowi jej wewnętrzną kwalifikację, konstytuuje niejako samą jej naturę 1 .

Praca stanowi również o poczuciu własnej wartości, będąc jednym z elementów przyrodzonej i niezbywalnej godności - należnej każdemu człowiekowi².

\section{Miejsce pracy w życiu osoby pozbawionej wolności}

Zgodnie z treścią art. $67 \$ 3$ Kodeksu karnego wykonawczego (dalej: K.k.w.) ${ }^{3}$ praca jest jednym z podstawowych środków oddziaływania na skazanych, które mają na celu zmianę postaw i zachowań w kierunku pożądanym społecznie. Stanowi zatem element prewencji szczególnej, określonej w art. $67 \$ 1$ K.k.w., w którym sformułowano cel kary jako kształtowanie społecznie pożądanych postaw skazanego, po-

$1 \quad$ Wybór tekstów źródłowych z historii doktryn polityczno-prawnych. Nauka społeczna Kościoła katolickiego od Leona XIII do Jana Pawła II, red. K. Biliński, M. Żmuda, Toruń 1997, s. 198.

2 Konstytucja RP z dnia 2 kwietnia 1997 r., tekst jednolity: Dz. U. z 1997 r. Nr 78, poz. 483.

3 Ustawa z dnia 6 czerwca 1997 r. - Kodeks karny wykonawczy, tekst jednolity: Dz. U. z 2019 r. poz. 676, 679, 1694, 2070; S. Lelental, Kodeks karny wykonawczy. Komentarz, Warszawa 2010, s. 513; T. Kalisz, Zatrudnienie skazanych odbywających kare pozbawienia wolności, Wrocław 2004, s. 181 i nast. 
czucia odpowiedzialności oraz potrzeby przestrzegania porządku prawnego i tym samym powstrzymania się od powrotu do przestępstwa.

Pracy nie należy jednak utożsamiać tylko z procesem fizycznym, stanowi ona bowiem proces złożonej aktywności fizycznoumysłowej człowieka, której celem jest przekształcenie środowiska przyrodniczego w ten sposób, by zwiększyć szansę gatunku ludzkiego na przeżycie ${ }^{4}$. Zatrudnienie więźniów pełni funkcje: represyjną, resocjalizacyjną, zdrowotno-higieniczną, ekonomiczną, wzmacniającą stan bezpieczeństwa w zakładzie karnym i zapobiegającą demoralizacji ${ }^{5}$.

Funkcja represyjna pracy w warunkach kary pozbawienia wolności powinna być oceniana negatywnie i jedynie z perspektywy historycznej. Już w I w. n.e., w czasach cesarstwa rzymskiego, można było zastosować karę pracy przymusowej, choć tylko do osoby niskiego pochodzenia. Była to praca w kopalni lub przymusowa praca publiczna, np. czyszczenie kloak czy ulic ${ }^{6}$. W czasach nowożytnych system pracy przymusowej stosowany był m.in. w hitlerowskich obozach koncentracyjnych czy systemie łagrów radzieckich, które funkcjonowały do końca lat 80. ubiegłego stulecia. Była to praca, która miała na celu jedynie wzmóc dolegliwość izolacji więziennej, rzadko miała uzasadnienie ekonomiczne.

W pedagogice resocjalizacyjnej, która zajmuje się procesem wychowania, praca jest jednym z jego głównych składowych. Celem wychowania natomiast jest ukształtowanie u skazanego prawidłowej postawy wobec pracy, opartego na procesach rzetelnego przygotowania do zawodu i szacunku do innych pracujących oraz wytworów ich pracy zarówno z punktu widzenia indywidualnego - odpowiedzialność, sumienność, rzetelność, dyscyplina, jak i społecznego - praca w oparciu o umowę o pracę lub inną prawem dozwoloną - zapewnia wypełnianie zarówno obowiązków wobec państwa (podatki, obowiązkowe składki), jak i przesłanek solidaryzmu społecznego, utrzymanie rodziny i siebie samego. Przygotowanie do zawodu w czasie odbywania kary pozbawienia wolności odbywa się z poszanowaniem zasad bezpieczeństwa i higieny pracy. Niemniej jednak ważne jest uwzględnienie: wykształcenia, zainteresowań i potrzeb skazanych podczas kierowania ich do pracy $^{7}$.

Zasadniczym obszarem, w którym dochodzi do kształtowania stosunku jednostki do prawa, podstawowych zasad moralnych, a także społecznie akceptowanego

4 Encyklopedia PWN, Warszawa 1996, s. 303.

5 M. Wilk, Znaczenie pracy w opiniach uwięzionych, w: Tożsamość osobowa dewiantów a ich reintegracja społeczna, cz.1, red. A. Kieszkowska, Kraków 2011, s. 412.

6 A. Barczyk, P.P. Barczyk, Wybrane zagadnienia historii resocjalizacji, Kraków 1999, s. 46.

7 Z. Hołda, w: Kodeks karny wykonawczy. Komentarz, red. Z. Hołda, K. Postulski, Gdańsk 2007, s. 450. 
systemu wartości, jest środowisko pracy ${ }^{8}$. Aby zrealizować ten cel, każde przedsiębiorstwo produkcyjne lub usługowe, zatrudniające osoby pozbawione wolności powinno mieć na uwadze m.in. cele służące procesowi readaptacji społecznej, spójne $\mathrm{z}$ celami wychowawczymi, tj.:

1) zdefiniowanie konkretnych celów (w tym istoty zatrudnienia);

2) logiczne sformułowanie oczekiwań dotyczących osiągnięć (zarówno z punktu widzenia indywidualnej satysfakcji, jak i celu ogólnego działalność przedsiębiorstwa);

3) wdrożenie systemu kar i nagród w ujęciu pedagogicznym;

4) zapewnienie sprzężenia zwrotnego, tj. rzetelnej, uczciwej i systematycznej oceny pracy;

5) zapewnienie ciągłości pracy zespołu pomimo fluktuacji zatrudnienia więźniów;

6) zapewnienie wzorcowej pracy zespołowej;

7) zapewnienie środków niezbędnych do osiągania celów;

8) wspomaganie szefów zespołów9.

Praca w warunkach instytucji totalnej nabiera szczególnego wymiaru. Jako często wykonywana poza murami więzienia stanowi przywilej umożliwiający kontakt ze światem zewnętrznym, co jest istotnym elementem procesu resocjalizacji osób skazanych, na który zwraca uwagę wielu badaczy ${ }^{10}$. Henryk Machel ${ }^{11}$ twierdził, że jest ona podstawowym elementem życia człowieka i dlatego czymś normalnym również w warunkach izolacyjnych. Nabiera ona charakteru resocjalizującego, gdy wywołuje u skazanych zmiany społecznie pożądane, także w systemie ich wartości. Wówczas jest wychowaniem przez pracę.

Obok funkcji: wychowującej, resocjalizacyjnej oraz readaptacyjnej należy wskazać funkcję ekonomiczną pracy, która przemawia jednoznacznie za potrzebą upowszechnienia możliwości jej wykonywania.

Skazani, nawet po osadzeniu, choć w sposób znacząco ograniczony, uczestniczą w życiu społecznym. Osadzenie często jedynie potęguje problemy ekonomiczne, z którymi borykali się wraz z rodzinami, będąc wolnymi. Poważnym problemem są stałe zobowiązania alimentacyjne, które - w razie braku pracy odpłatnej, pozostają nierealizowane. W takich przypadkach dług ten narasta do rozmiaru, który nie

8 B. Hołyst, Kryminologia, Warszawa 2009, s. 1027.

9 A. Hardingham, Praca w zespole, Warszawa 1998, s. 58.

10 T. Szymanowski, Funkcje zatrudnienia skazanych w świetle danych empirycznych, w: Praca skazanych odbywających karę pozbawienia wolności, red. T. Bojarski, Z. Hołda, J. Baranowski, Lublin 1985, s. 53; T. Kalisz, Zatrudnienie skazanych odbywających karę pozbawienia wolności, Wrocław 2004, s. 15 i nast.

11 H. Machel, Więzienie jako instytucja karna i resocjalizacyjna, Gdańsk 2003, s. 259-260. 
może być wypełniony przez skazanego po opuszczeniu jednostki penitencjarnej, stając się problemem społecznym, gdyż realizowany jest wówczas ze środków publicznych. Według dostępnych danych tylko w pierwszym półroczu 2018 r. wszczęto ponad 90 tys. spraw przeciw dłużnikom alimentacyjnym i 39 tys. spraw karnych z art. 209 Kodeksu karnego (dalej: K.k.) ${ }^{12}$.

Funkcje: wzmacniająca stan bezpieczeństwa oraz zapobiegająca demoralizacji wśród skazanych polegają na tym, że zatrudnienie służy utrzymaniu dyscypliny na terenie jednostki penitencjarnej. Jest sposobem na nudę, z której wynika patologia więzienna, np. wzajemne znęcanie się więźniów nad sobą, zbiorowe bunty, agresja, przemoc. W nowoczesnych placówkach penitencjarnych nie może zabraknąć szerokich możliwości zatrudnienia skazanych. Oznacza to konieczność szkoleń i działań aktywizacyjnych oraz wsparcie w aktywizacji, np. poradnictwo zawodowe, grupowe i indywidualne, a także z prawa pracy. Przydatne są również szkolenia $\mathrm{z}$ zakresu poruszania się na rynku pracy. UE rekomenduje, aby w reintegrację zawodową więźniów włączać organizacje pozarządowe zajmujące się rynkiem pracy, agencje rządowe, osoby prywatne, a także skazanych wraz z rodzinami i osoby pokrzywdzone oraz poszkodowane ${ }^{13}$.

Praca skazanego pełni również ważną rolę w procesie jego readaptacji społecznej rozumianej jako

powrót do społeczeństwa, który charakteryzuje się nie tylko powstrzymaniem się od popełniania przestępstw, ale także właściwym funkcjonowaniem w społeczności (w środowisku rodzinnym, pracy, sąsiedztwie czy też grupie rówieśniczej), czyli przestrzeganiem nie tylko norm prawnych, ale również społecznych i podstawowych norm etycznych ${ }^{14}$.

Członkowie rodzin skazanych są niezbędnymi podmiotami uczestniczącymi w sposób bezpośredni w procesie wsparcia zatrudnienia swoich bliskich opuszczających zakład karny i próbujących podjąć pracę w warunkach wolnościowych, bez wsparcia instytucjonalnego ze strony pracowników penitencjarnych, którzy udzielali im pomocy podczas odbywania kary pozbawienia wolności ${ }^{15}$.

12 Biuro Informacji Kredytowej, Raport - Dłużnik alimentacyjny, InfoMonitor 2018, nr 9, s. 1.

13 M. Wilk, Znaczenie pracy w opiniach uwięzionych, w: Tożsamość osobowa dewiantów..., s. 413.

14 T. Szymanowski, w: Kodeks karny wykonawczy. Komentarz, T. Szymanowski, Z. Świda, Warszawa 1998, s. 150.

15 T. Szymanowski, Powrót skazanych do społeczeństwa, Warszawa 1989, s. 177. 


\section{Fundusz Aktywizacji Zawodowej Skazanych oraz Rozwoju Przywięziennych Zakładów Pracy w procesie readaptacji społecznej skazanych}

Mechanizmem finansowym, który służy wzmocnieniu pozycji osadzonego na rynku pracy, jest Fundusz Aktywizacji Zawodowej Skazanych oraz Rozwoju Przywięziennych Zakładów Pracy (dalej: Fundusz Aktywizacji). Swoje źródło znajduje w środkach wypracowanych przez skazanych w jednostkach penitencjarnych.

Zasobność finansowa Funduszu Aktywizacji jest zależna od liczby skazanych, którzy pracują odpłatnie. W latach 2010-2016 r. notowano systematyczny spadek liczby osób odbywających karę pozbawienia wolności otrzymujących wynagrodzenie za pracę. Zjawisko to było konsekwencją orzeczenia Trybunału Konstytucyjnego (dalej: TK) z dnia 23 lutego 2010 r. ${ }^{16}$ Zgodnie z nim więźniom przysługiwało co najmniej minimalne wynagrodzenie za wykonywaną pracę. Tym samym przedsiębiorcy sektora prywatnego rzadziej ich zatrudniali. Trybunał Konstytucyjny zakwestionował pojęcie „połowy” w zdaniu pierwszym art. $123 \$ 2$ K.k.w., tj. „Wynagrodzenie przysługujące skazanemu zatrudnionemu w pełnym wymiarze czasu pracy ustala się w sposób zapewniający osiągnięcie co najmniej połowy [wyróżnienie - A.L. -Z.] minimalnego wynagrodzenia określonego na podstawie odrębnych przepisów $w$ myśl art. 32 oraz z art. 65 ust. 4 w związku z art. 2 konstytucji”. Zdaniem Trybunału wprowadzone rozwiązanie stwarza możliwość nieuzasadnionego zaniżania wynagrodzenia za pracę wypłaconego osobom skazanym i czerpania tym samym przez pracodawców nieuzasadnionych korzyści z takiego zatrudnienia. W ocenie Trybunału istnieją alternatywne środki obniżania kosztów pracy osób skazanych, nieprowadzące do obniżania wynagrodzenia za pracę poniżej poziomu wynagrodzenia minimalnego. W związku z tym zaskarżony przepis nie spełnia kryteriów dopuszczalnego różnicowania podmiotów podobnych i narusza konstytucyjną zasadę równości. Jak podkreślił Trybunał, ustawodawca ma pełną swobodę regulacyjną w zakresie ustalania poziomu minimalnego wynagrodzenia. Nie może ono jednak być określane w sposób dowolny, a w każdym przypadku musi zapewniać zatrudnionym możliwość zaspokojenia ich podstawowych potrzeb. Wynagrodzenie nie może być ustalane na dowolnie niskim poziomie. W przeciwnym wypadku instytucja minimalnego wynagrodzenia pozbawiona byłaby jakiegokolwiek sensu. Trybunał Konstytucyjny orzekł, że ustanowione różnicowanie poziomu minimalnego wynagrodzenia w oparciu o kryterium statusu osoby pozbawionej wolności

Wyrok TK z dnia 23 lutego 2010 r., P 20/09 (wszedł w życie z dniem 9 marca 2011 r.). 
ma charakter arbitralny i narusza konstytucyjne zasady kształtowania minimalnego wynagrodzenia ${ }^{17}$.

Mając na uwadze, że przychód Funduszu Aktywizacji stanowią niemalże w całości potrącenia $\mathrm{z}$ wynagrodzenia skazanych, należało przewidywać spadek jego wpływów i tym samym zmniejszenie możliwości wsparcia finansowego osób, dla których został utworzony. Do 2016 r. nie podejmowano jednak skutecznych działań służących wprowadzeniu rozwiązań systemowych w tym zakresie. W kolejnych latach Służba Więzienna, mając na uwadze rolę pracy, która jest jednym z filarów resocjalizacji, szybko zareagowała, doprowadzając do wzrostu liczby więźniów pracujących nieodpłatnie, tj. z poziomu 8052 osób w 2010 r. do 14879 w 2013 r. ${ }^{18}$

Fundusz Aktywizacji został wprowadzony ustawą z dnia 28 sierpnia 1997 r. o zatrudnianiu osób pozbawionych wolności w miejsce Funduszu Rozwoju Przywięziennych Zakładów Pracy ${ }^{19}$. Niniejszy mechanizm finansowy jest funduszem celowym, którego dysponentem jest Dyrektor Generalny Służby Więziennej. Jego przychodami są:

1) wpłaty przywięziennych zakładów pracy, w wysokości co najmniej 25\% środków uzyskanych z tytułu zwolnień określonych w art. 6 ust. 1 i 2 u.z.p.w.;

2) środki pieniężne pochodzące ze spadków, zapisów, darowizn, dotacji, zbiórek i innych źródeł;

3) środki pieniężne pochodzące z potrącenia określonego w art. $125 \$ 1$ K.k.w. Zwolnienia przywięziennych zakładów pracy, o których mowa w art. 6 ust. 1 u.z.p.w. (z zastrzeżeniem art. 6 ust. 2 i 3), obejmują:

1) podatek dochodowy od osób prawnych, w zakresie i na zasadach określonych w przepisach o tym podatku;

2) niepodatkowe należności budżetowe;

3) wpłaty na Państwowy Fundusz Rehabilitacji Osób Niepełnosprawnych;

4) opłaty z tytułu użytkowania lub użytkowania wieczystego gruntów stanowiących własność Skarbu Państwa - jeżeli średnioroczne zatrudnienie osób pozbawionych wolności w przeliczeniu na pełne etaty w poprzednim roku podatkowym wynosiło co najmniej 50\% ogółu zatrudnionych.

17 Trybunał Konstytucyjny, Zasady ustalania wynagrodzenia skazanego zatrudnionego w pełnym wymiarze czasu pracy, http://www.trybunal.gov.pl/postepowanie-i-orzeczenia/komunikatyprasowe/ komunikaty-po/art/2725-zasady-ustalania-wynagrodzenia-skazanego-zatrudnionego-wpełnymwymiarze-czasu-pracy [dostęp: 04.05.2020 r.].

18 Służba więzienna, Statystyka, http://www.sw.gov.pl/dzial/statystyka [dostęp: 30.10 .2019 r.]

19 Ustawa z dnia 28 sierpnia 1997 r. o zatrudnianiu osób pozbawionych wolności, tekst jednolity: Dz. U. z 2014 r. poz. 1116 (dalej: u.z.p.w.). 
W przypadku, gdy w poprzednim roku podatkowym średnioroczne zatrudnienie osób pozbawionych wolności w przeliczeniu na pełne etaty stanowiło mniej niż 50\% ogółu zatrudnionych, wymienione zwolnienia wynoszą:

1) $25 \%$ przy zatrudnieniu co najmniej $20 \%$ osób pozbawionych wolności;

2) $50 \%$ przy zatrudnieniu co najmniej $30 \%$ osób pozbawionych wolności;

3) $75 \%$ przy zatrudnieniu co najmniej $40 \%$ osób pozbawionych wolności.

Jeżeli w poprzednim roku podatkowym zatrudnienie osób pozbawionych wolności w przeliczeniu na pełne etaty wynosiło mniej niż $20 \%$ ogółem zatrudnionych, zwolnienia, o których mowa w pkt. 2-4, nie przysługują.

Przywięzienne zakłady pracy rozpoczynające działalność korzystają ze zwolnień, o których mowa w pkt. 2-4, w pełnej wysokości w roku podatkowym, w którym nastąpiło ich zarejestrowanie.

Po zmianie zasad określonych w art. $125 \$ 1$ K.k.w..$^{20} \mathrm{z}$ wynagrodzenia za pracę przysługującego skazanemu potrąca się 7\% na cele Funduszu określone w art. 43 $\$ 8$ (Funduszu Pomocy Postpenitencjarnej) oraz $45 \%$ na cele Funduszu Aktywizacji Zawodowej Skazanych oraz Rozwoju Przywięziennych Zakładów Pracy, utworzonego na podstawie art. 6a ustawy z dnia 28 sierpnia 1997 r. o zatrudnianiu osób pozbawionych wolności ${ }^{21}$. Ustawa weszła w życie z dniem 1 kwietnia $2017 \mathrm{r}$.

Do tego czasu skazanemu $z$ wynagrodzenia za pracę potrącano $10 \%$ na cele Funduszu Pomocy Postpenitencjarnej oraz 25\% na cele Funduszu Aktywizacji Zawodowej Skazanych oraz Rozwoju Przywięziennych Zakładów Pracy.

Zgodnie z dyspozycją przepisu art. 8 ust.1 u.z.p.w. środki Funduszy Aktywizacji Zawodowej Skazanych oraz Rozwoju Przywięziennych Zakładów Pracy przeznacza się na: tworzenie nowych miejsc pracy dla osób pozbawionych wolności oraz ochronę istniejących, tworzenie w zakładach karnych infrastruktury niezbędnej dla działań resocjalizacyjnych, modernizację przywięziennych zakładów pracy i ich produkcji, organizowanie nauki zawodu i doskonalenia zawodowego dla osób pozbawionych wolności, organizowanie szkolenia w zakresie aktywizacji zawodowej i umiejętności poszukiwania pracy. Z tytułu zwiększonych kosztów zatrudnienia osób pozbawionych wolności przedsiębiorcy zatrudniający te osoby otrzymują ze środków Funduszu Aktywizacji ryczałt w wysokości 20\% (40\% po zmianie ustawy) ${ }^{22}$

20 Ustawa z dnia 15 grudnia 2016 roku o zmianie ustawy - Kodeks karny wykonawczy, tekst jednolity: Dz. U. z 2017 r. poz. 204.

21 Ustawa z dnia 28 sierpnia 1997 r. o zatrudnianiu osób pozbawionych wolności, tekst jednolity: Dz. U. z 2017 r. poz. 2151.

22 Zgodnie z projektem Ministerstwa Sprawiedliwości (Druk Sejmowy nr 931) nowelizowany jest art. 8 ust. 2 ustawy o zatrudnianiu osób pozbawionych wolności: z tytułu zwiększonych kosztów zatrudnienia osób pozbawionych wolności przedsiębiorcy zatrudniający te osoby otrzymują ze środków Funduszu Aktywizacji ryczałt w wysokości 40\% wartości wynagrodzeń przysługujących 
wartości wynagrodzeń przysługujących zatrudnionym osobom pozbawionym wolności; wypłata ryczałtu następuje na wniosek tych przedsiębiorców. Ze środków Funduszu Aktywizacji mogą być przyznawane pożyczki bądź dotacje podmiotom zatrudniającym osoby pozbawione wolności.

Celem udzielania pomocy finansowej z Funduszu Aktywizacji jest wspieranie rozwoju rynku pracy skazanych, w szczególności poprzez finansowanie działań służących ochronie i tworzeniu miejsc pracy dla tych osób. W sposób pośredni działanie to służy także ułatwieniu skazanym powrotu na rynek pracy po odbyciu kary poprzez przyuczenie do zawodu, uzyskanie koniecznych uprawnień, zaświadczeń, certyfikatów, a także świadectwa pracy.

Szczegółowe zasady oraz tryb finansowania działań w zakresie resocjalizacji osób pozbawionych wolności, o których mowa w art. 8 ust. 1 ustawy; szczegółowe zasady, tryb i terminy wypłaty ryczałtu z tytułu zwiększonych kosztów zatrudnienia osób pozbawionych wolności, zwanego dalej „ryczałtem”, przedsiębiorcom zatrudniającym te osoby; szczegółowe zasady, tryb i terminy udzielania pożyczek i dotacji podmiotom zatrudniającym osoby pozbawione wolności; sposób i tryb dokumentowania: wydatków na zatrudnienie osób pozbawionych wolności, wysokości i przeznaczenia pomoc wraz z wzorami dokumentów w tych sprawach określa rozporządzenie z dnia 23 stycznia 2012 r. w sprawie Funduszu Aktywizacji Zawodowej Skazanych oraz Rozwoju Przywięziennych Zakładów Pracy ${ }^{23}$.

Do podstawowych działań Funduszu Aktywizacji należy wspomaganie pracodawców poprzez wypłatę ryczałtu, z tytułu zwiększonych kosztów zatrudnienia osób pozbawionych wolności w wysokości $40 \%$ (przed nowelizacją ustawy 20\%) wartości wynagrodzeń przysługujących zatrudnionym osobom pozbawionym wolności. Wypłata ryczałtu następuje na wniosek przedsiębiorcy, złożony za pośrednictwem jednostki organizacyjnej Służby Więziennej, która skierowała osoby pozbawione wolności do zatrudnienia u przedsiębiorcy. Zarówno wzór wniosku, jak i szczegółowe zasady postępowania określa cyt. rozporządzenie.

W rozporządzeniu zawarto także szczegółowy opis trybu udzielania pożyczek i dotacji z Funduszu Aktywizacji. Pomoc ta jest przyznawana na wniosek podmiotu zatrudniającego osoby pozbawione wolności oraz realizującego działania w zakresie resocjalizacji tych osób, składany bezpośrednio do dysponenta Funduszu

zatrudnionym osobom pozbawionym wolności; wypłata ryczałtu następuje na wniosek tych przedsiębiorców. Zgodnie z ust. 2a. projektu, przepis ust. 2 stosuje się od dnia, w którym Komisja Europejska wydała pozytywną decyzję o zgodności pomocy publicznej z rynkiem wewnętrznym, i obowiązuje w okresie jej obowiązywania.."

23 Rozporządzenie z dnia 23 stycznia 2012 r. w sprawie Funduszu Aktywizacji Zawodowej Skazanych oraz Rozwoju Przywięziennych Zakładów Pracy, tekst jednolity: Dz. U. z 2014 r. poz. 53. 
Aktywizacji - Dyrektora Generalnego Służby Więziennej. Wniosek o udzielenie pożyczki bądź dotacji poddawany jest dwuetapowej kwalifikacji przez komisję powołaną przez dysponenta Funduszu Aktywizacji. Procedura przyznawania pomocy w postaci pożyczki bądź dotacji kończy się zawarciem umowy pomiędzy dysponentem Funduszu Aktywizacji a podmiotem zatrudniającym osoby pozbawione wolności. Podmiot, który otrzymał pożyczkę bądź dotację, jest zobowiązany do zatrudniania osób pozbawionych wolności przez okres i na zasadach określonych w umowie. Dysponent Funduszu Aktywizacji jest uprawniony do kontroli podmiotu, z którym została zawarta umowa.

Decyzją Komisji Europejskiej z dnia 11 stycznia 2012 r. rozszerzono program pomocy publicznej dla przedsiębiorców zatrudniających osoby pozbawione wolności N519/2007 o ryczałt, o którym mowa w rozporządzeniu Ministra Sprawiedliwości z dnia 23 stycznia 2012 r. w sprawie Funduszu Aktywizacji Zawodowej Skazanych oraz Rozwoju Przywięziennych Zakładów Pracy. Pomoc państwa nr SA.33608 (2011/N) spełnia kryteria zgodności z art. 107 ust. 3 lit. c) TFUE. Obsługą Funduszu Aktywizacji Zawodowej Skazanych oraz Rozwoju Przywięziennych Zakładów Pracy zajmuje się Biuro Kwatermistrzowsko-Inwestycyjne Centralnego Zarządu Służby Więziennej ${ }^{24}$. Jak wspomniano, bezpośrednim powodem zapaści w systemie zatrudnienia odpłatnego skazanych był brak odpowiedniej reakcji na opisany już wyrok TK z $2010 \mathrm{r}$.

Z dostępnych danych wynika, że ogólna liczba pracujących skazanych po wydaniu wyroku TK zmniejszyła się. Prima facie spadek ów nie był wysoki, na przestrzeni lat 2010-2012 wyniósł bowiem zaledwie 3,2\%, by ponownie wzrastać do 2015 r. do poziomu 36,1\%, czyli wyższego aniżeli tego, który obserwowano w $2011 \mathrm{r}$.

Aby jednak zrozumieć ten swoisty fenomen, należy bliżej przyjrzeć się porównaniu liczby skazanych pracujących odpłatnie i nieodpłatnie w tym samym okresie, korzystając z poniższego zestawienia.

Z obserwacji długookresowej wynika, że regres w zakresie liczby osób pracujących rozpoczął się już na przełomie 2007 i 2008 r. Okazuje się, że nawet rekordowo wysoki poziom zatrudnienia odpłatnego, tj. 21471 skazanych, przy także wyjątkowo wysokiej liczbie skazanych - 89995 na koniec 2007 r., dawał zaledwie 35,7\% skazanych pracujących w ogólnej liczbie osób pozbawionych wolności. W kolejnych latach liczba pracujących odpłatnie drastycznie spadła $z$ ok. 16,2 tys. na koniec 2009 r. do zaledwie 8,97 tys. na koniec 2013 r. Aby zrekompensować utratę miejsc pracy odpłatnej, Służba Więzienna podjęła z sukcesem proces odbudowania

24 Służba więzienna, Fundusz Aktywizacji Zawodowej Skazanych oraz Rozwoju Przywięziennych Zakładów Pracy, https://bip.sw.gov.pl/Strony/FunduszeAktyw.aspx [dostęp: 27.10.2019 r.]. 
rynku pracy nieodpłatnej i wolontariatu. Liczba ta wzrastała systematycznie w latach 2010-2018 z poziomu 8 do 19,2 tys.

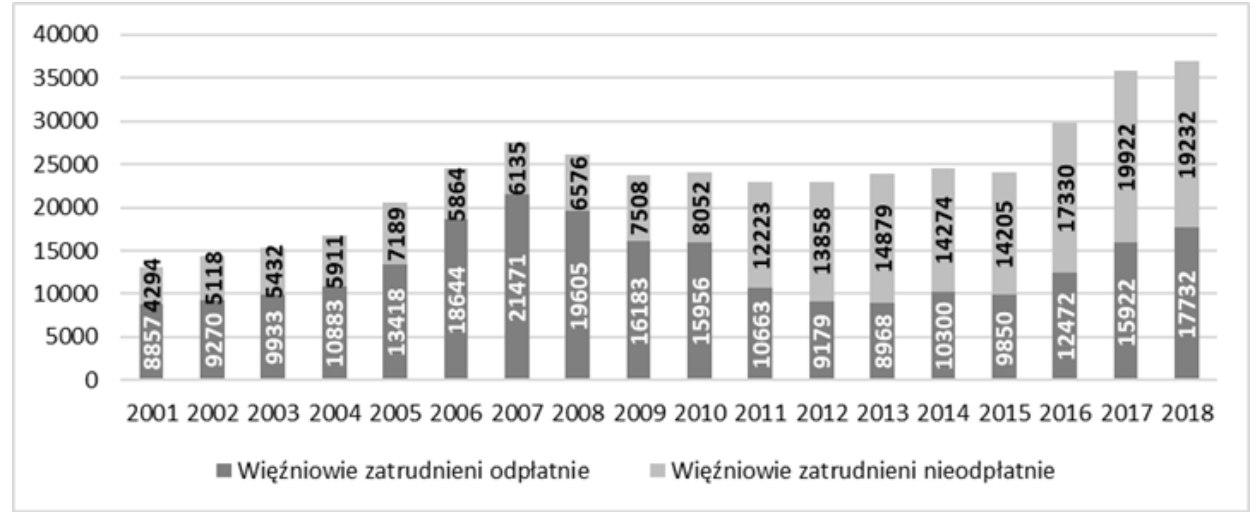

Wykres 1. Zatrudnienie więźniów w latach 2001-2018 na dzień 31 grudnia Źródło: opracowanie własne na podstawie: Służba więzienna, Statystyka roczna, http://www.sw.gov.pl/ strona/statystyka-roczna [dostęp: 30.01.2020 r.].

Podobny wzrost po stronie liczby osób zatrudnionych odpłatnie odnotowano w krótkim okresie od czasu wdrożenia rządowego programu „Praca dla więźniów”, tj. w latach 2015-2018, z poziomu 9,8 do 17,7 tys. osób.

\section{Podstawowe założenia programu „Praca dla więźniów"}

Ogłoszony przez Ministerstwo Sprawiedliwości program „Praca dla więźniów”25 zakładał m.in. rozszerzenie zakresu możliwości wykonywania nieodpłatnej pracy więźniów na rzecz samorządu, budowę 40 hal produkcyjnych przy zakładach karnych i podniesienie ulg dla przedsiębiorców zatrudniających więźniów.

Wśród korzyści wynikających z realizacji programu wymienia się w szczególności: wzrost zatrudnienia skazanych o prawie 12 tys. osadzonych, wzrost wskaźnika powszechności zatrudnienia skazanych do ok. 55,5\% oraz wzrost wskaźnika

25 Służba więzienna, Program „Praca dla więźniów”, założenia programu, https://sw.gov.pl/strona/ ministerialny-program-pracy-wiezniow [dostęp: 27.10.2019 r.]; Służba więzienna, Program „Paca dla więźniów", https://sw.gov.pl/dzial/program-pracy-wiezniow [dostęp: 27.10.2019 r.]. 
zatrudnienia w grupie skazanych zdolnych do pracy do ponad 83\%. Obecnie pracuje ponad 37 tys. osób pozbawionych wolności (dane na koniec lipca 2019 r.). W 2018 r. skazani przepracowali nieodpłatnie w skali kraju prawie 2 mln roboczogodzin o wartości ponad 25 mln zł. Dzięki programowi w 2018 r. kwota potrąceń z wynagrodzeń osadzonych posiadających zobowiązania alimentacyjne wyniosła ponad $14 \mathrm{mln}$ zł. Większa liczba pracujących skazanych to większe środki finansowe z potrąceń od ich wynagrodzeń przeznaczane na Fundusz Aktywizacji Zawodowej Skazanych oraz Rozwoju Przywięziennych Zakładów Pracy, z którego finansuje się budowę obiektów produkcyjnych, zatrudniających kolejnych skazanych. Większa liczba pracujących więźniów to większe środki finansowe z potrąceń od ich wynagrodzeń, przeznaczane również na wypłacanie przedsiębiorcom ryczałtu z tytułu zwiększonych kosztów zatrudnienia osób pozbawionych wolności, który w wyniku zainicjowanych w ramach programu działań legislacyjnych Ministerstwa Sprawiedliwości oraz Służby Więziennej wzrósł z 20 do 35\% wartości przysługujących skazanym wynagrodzeń. Z informacji udostępnianych przez Służbę Więzienną wynika, że w latach 2016-2019 ukończono i oddano do eksploatacji 25 obiektów produkcyjnych, a kolejnych 18 jest $\mathrm{w}$ trakcie realizacji ${ }^{26}$.

Więźniowie mogą obok pracy odpłatnej wykonywać pracę nieodpłatną (na wymiar większy niż 90 godzin miesięcznie muszą wyrazić zgodę). W tym celu poszerzono katalog podmiotów, w których mogą oni ją podejmować. Poza organami administracji publicznej i pożytku publicznego oraz jednostkami organizacyjnymi Służby Więziennej wskazano na:

- „podmioty, dla których organ gminy, powiatu lub województwa są organami założycielskimi,

- państwowe lub samorządowe jednostki organizacyjne,

- spółki prawa handlowego z wyłącznym udziałem Skarbu Państwa lub gminy, powiatu bądź województwa,

- młodzieżowe ośrodki socjoterapii,

- młodzieżowe ośrodki wychowawcze,

- placówki służby zdrowia,

- fundacje i stowarzyszenia,

- organizacje charytatywne"27.

26 Służba więzienna, Program „Praca dla więźniów”, założenia programu.

27 https://www.fundacja.lexnostra.pl/2016/09/21/program-pracy-wiezniow-rzad-przyjal-projekt-ustawy/ [dostęp: 04.05.2020 r.]. 
Rola Funduszu Aktywizacji Zawodowej Skazanych w społecznej readaptacji

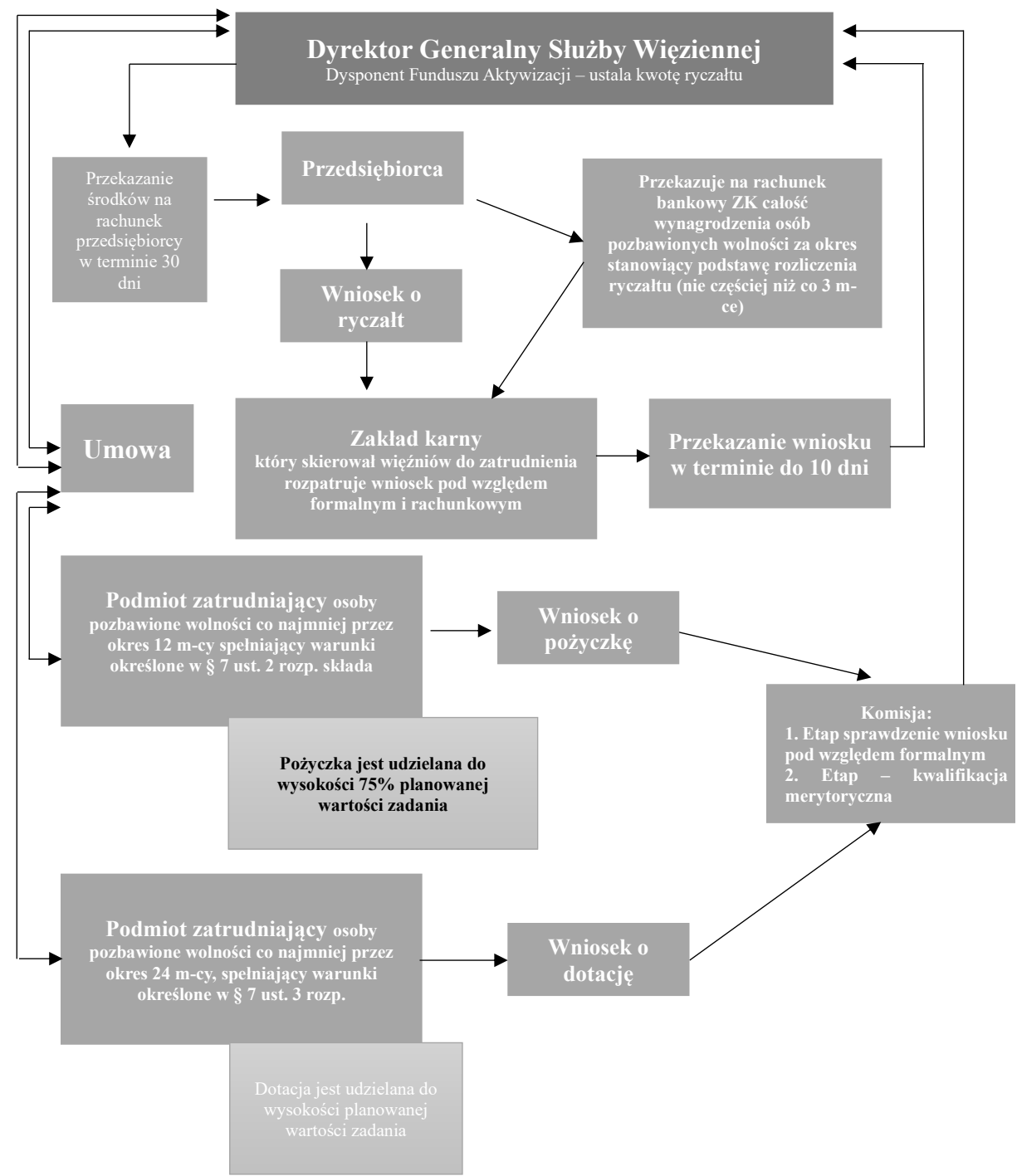

Schemat 1. Funkcjonowanie Funduszu Aktywizacji Zawodowej

Źródło: opracowanie własne. 


\section{Zakończenie}

Rozwijany od 2015 r. program, który zaprezentowano na schemacie 1, służy upowszechnieniu pracy osób odbywających karę pozbawienia wolności, w szczególności odpłatnej. Stopniowo przynosi zamierzone efekty. Niemniej jednak osiągnięcie jego podstawowych wskaźników nastąpi w 2020 r. Już teraz jednak należy zastanowić się nad szerszym spektrum możliwości jego wykorzystania w praktyce i w nauce, w szczególności zaprogramowaniem badań ewaluacyjnych w zakresie przydatności konkretnie prowadzonych działalności zakładów zatrudniających więźniów dla ich aktywizacji na rynku pracy po zakończeniu odbywania kary pozbawienia wolności w środowisku otwartym, celem jej dalszego profilowania. Niewątpliwie bowiem możliwość zatrudniania skazanych, która wiąże się ze znacznymi oszczędnościami po stronie pracodawców, nie powinna przesłaniać podstawowego celu kary pozbawienia wolności w specjalnie zaaranżowanych warunkach, jakim jest przywrócenie skazanego społeczeństwu.

\section{Bibliografia}

Barczyk A., P.P. Barczyk P.P., Wybrane zagadnienia historii resocjalizacji, Kraków 1999.

Biuro Informacji Kredytowej, Raport - Dłużnik alimentacyjny "InfoMonitor 2018, nr 9. Encyklopedia PWN, Warszawa 1996.

Hołda Z., Kodeks karny wykonawczy. Komentarz, w: Kodeks karny wykonawczy. Komentarz, red. Z. Hołda, K. Postulski, Gdańsk 2007.

Hołyst B., Kryminologia, Warszawa 2009.

Kalisz T., Zatrudnienie skazanych odbywających karę pozbawienia wolności, Wrocław 2004.

Kondycja organizacji pozarzadowych. Raport $z$ badań 2018, https://fakty.ngo.pl/raporty/ kondycja-organizacji-pozarzadowych-2018 [dostęp: 27.10.2019 r.].

Lelental S., Kodeks karny wykonawczy. Komentarz, Warszawa 2010.

Machel H., Więzienie jako instytucja karna i resocjalizacyjna, Gdańsk 2003.

Ministerstwo Sprawiedliwości, Pomoc postpenitencjarna, https://arch-bip.ms.gov.pl/pl/ dzialalnosc/fundusz-sprawiedliwosci/pomoc-postpenitencjarna/[dostęp: 27.10.2019 r.].

Ministerstwo Sprawiedliwości, Pomoc postpenitencjarna, I otwarty Konkurs ofert na lata 2020-2022 - Pomoc Postpenitencjarna - Warszawa, https://www.funduszsprawiedliwosci.gov.pl/pl/konkursy/pomoc-postpenitencjarna/news,15339,i-otwarty-konkurs-ofert -na-lata-2020-2022--pomoc.html [dostęp: 27.10.2019 r.].

Program pracy więżniów, https://www.fundacja.lexnostra.pl/2016/09/21/program-pracy -wiezniow-rzad-przyjal-projekt-ustawy/ [dostęp: 04.05.2020 r.]. 
Służba więzienna, Fundusz Aktywizacji Zawodowej Skazanych oraz Rozwoju Przywięziennych Zakładów Pracy, https://bip.sw.gov.pl/Strony/FunduszeAktyw.aspx [dostęp: 27.10.2019 r.].

Służba więzienna, Statystyka, http://www.sw.gov.pl/dzial/statystyka [dostęp: 30.10.2019 r.].

Służba więzienna, Statystyka roczna, http://www.sw.gov.pl/strona/statystyka-roczna [dostęp: 27.10.2019 r.].

Służba Więzienna, Program pracy dla więźniów, https://sw.gov.pl/dzial/program-pracy-wiezniow [dostęp: 27.10.2019 r.].

Służba więzienna, Program „Praca dla więźniów”, założenia programu, https://sw.gov.pl/ strona/ministerialny-program-pracy-wiezniow [dostęp: 27.10.2019 r.].

Szymanowski T., Funkcje zatrudnienia skazanych $w$ świetle danych empirycznych, w: Praca skazanych odbywajacych kare pozbawienia wolności, red. T. Bojarski, Z. Hołda, J. Baranowski, Lublin 1985.

Szymanowski T., Powrót skazanych do społeczeństwa, Warszawa 1989.

Szymanowski T., Kodeks karny wykonawczy. Komentarz, w: Kodeks karny wykonawczy. Komentarz, red. T. Szymanowski, Z. Świda, Warszawa 1998.

Trybunał Konstytucyjny, Zasady ustalania wynagrodzenia skazanego zatrudnionego w peknym wymiarze czasu pracy, http://www.trybunal.gov.pl/postepowanie-i-orzeczenia/ komunikatyprasowe/komunikaty-po/art/2725-zasady-ustalania-wynagrodzenia -skazanego-zatrudnionego-wpełnym-wymiarze-czasu-pracy [dostęp: 04.05.2020 r.]

Wiatrowski Z., Postawy pedagogiki pracy, Bydgoszcz 1997.

Wilk M., Znaczenie pracy w opiniach uwięzionych, w: Tożsamość osobowa dewiantów a ich reintegracja społeczna, cz. 1., red. A. Kieszkowska, Kraków 2011, s. 411-421.

Wybór tekstów źródłowych z historii doktryn polityczno-prawnych. Nauka społeczna Kościoła katolickiego od Leona XIII do Jana Pawła II, red. K. Biliński, M. Żmuda, Toruń 1997. 
